\title{
Fiber Reinforced Concrete
}

\author{
GALAJU SANKARACHARI \\ Pursuing M.Tech (STRUCTURAL) from SKR \\ College of Engineering \& Technology, Manubolu, \\ SPSR Nellore.
}

\author{
R. BALAMURUGAN \\ Ph.D, Associate Professor in Deportment of Civil, \\ SKR College of Engineering \& Technology, \\ Manubolu, SPSR Nellore
}

Abstract: The present day world is seeing the development of exceptionally difficult and troublesome structural designing structures. Regularly, concrete being the most vital and broadly utilized material is called upon to have high quality and adequate functionality properties. Endeavors are being made in the field of solid innovation to grow such cements with extraordinary attributes. Specialists everywhere throughout the world are endeavoring to grow elite cements by utilizing strands and different admixtures in concrete up to specific extents. In the perspective of the worldwide reasonable advancements, it is basic that filaments like glass, carbon, polypropylene and aramid strands give upgrades in elasticity, weariness qualities, toughness, shrinkage attributes, affect, cavitation, disintegration obstruction and functionality of cement. Strands give vitality assimilation, sturdiness and effect opposition properties to fiber strengthened solid material and these qualities thusly enhance the crack and exhaustion properties of fiber fortified solid research in glass fiber fortified cement brought about the advancement of a soluble base obstruction filaments high scattering that enhanced long haul solidness. This framework was named salt opposition glass fiber fortified cement. In the present trial examination the salt obstruction glass filaments has been utilized to think about the impact on compressive, split elastic and flexural quality on M20, M30, M40 and M50 evaluations of cement

\section{INTRODUCTION}

Concrete is the most broadly utilized development material has a few attractive properties like high compressive quality, solidness and sturdiness under regular ecological components. In the meantime concrete is fragile and frail in strain. Plain concrete has two insufficiencies, low rigidity and a low endure crack. These deficiencies are for the most part overwhelmed by strengthening concrete. Regularly fortification comprises of nonstop distorted steel bars or pre-focusing on ligaments. The benefit of fortifying and pre-focusing on innovation using steel support as high elastic steel wires have helped in conquering the inadequacy of cement in strain yet the flexibility size of compressive quality.

Fiber strengthened cement (FRC) is a solid made essentially of water powered concretes, totals and discrete fortifying strands. FRC is a generally new material. This is a composite material comprising of a grid containing an irregular dissemination or scattering of little filaments, either regular or fake, having a high rigidity. Because of the nearness of these consistently scattered filaments, the breaking quality of cement is expanded and the strands going about as split arresters. Strands reasonable of fortifying cement having been delivered from steel, glass and natural polymers. A large number of the present utilizations of FRC include the utilization of strands going around $1 \%$ by volume of cement. Late endeavors made it conceivable to join moderately extensive volumes of steel, glass and manufactured strands in concrete. Consequences of malleable tests done on cements with glass, polypropylene and steel strands, show that with such huge volume of adjusted filaments in concrete, there is considerable upgrade of the pliable load conveying limit of the grid. This might be ascribed to the reality strands smother the limitation of miniaturized scale breaks into large scale splits and subsequently the clear elasticity of the framework increments.

\section{SURVEY OF LITERATURE}

Griffiths led concentrate to examine the mechanical properties of glass fiber fortified polyester polymer concrete. The creator watched that the modulus of break of polymer concrete containing 20\% polyester pitch and around $79 \%$ fine silica total is around $20 \mathrm{MPa}$. The expansion of around 1.5\% cleaved glass strands (by weight) to the material builds the modulus of break by around $20 \%$ and the crack strength by around 55\%. Glass filaments enhance the quality of the material by expanding the power required for disfigurement and enhance the strength by expanding the vitality required for break proliferation. Sorousshian detailed the consequences of a trial examine on the relative adequacy of various kinds of steel fiber in concrete. The creator watched that the incorporation of strands diminishes the usefulness of crisp cement and this impact is more articulated for filaments with higher perspective proportions. The impacts of fiber compose on crisp blend functionality, as spoke to both emotionally and by the modified droop and cone time, appear to be unimportant. Pleated strands result in somewhat higher droop esteems when contrasted and straight and snared filaments. Rao contemplated the impact of glass strands on the mechanical properties of M20 and M30 evaluations of cement. Babu examined the expansion of the glass filaments and reasoned that there is increment in the compressive quality upto 
$1 \%$ by volume at higher fiber rates and the quality declines if the fiber content is expanded essentially.

\section{MATERIALS AND METHODS}

Materials

\section{Cement}

Ordinary Portland cement of 53 grades available in local market is used in the investigation. The cement used has been tested for various proportions as per IS: 4031-1988 and found to be conforming to various specifications of IS: $12269-1987$. The specific gravity was 3.02 and the fineness was 3200 $\mathrm{cm}^{2} / \mathrm{gm}$

\section{Coarse aggregate}

Crushed angular granite metal from a local source was used as coarse aggregate. The specific gravity was 2.71 , flakiness index of 4.58 percent and elongation index of 3.96 .

\section{Fine aggregate}

River sand was used as fine aggregate. The specific gravity and fineness modulus was 2.55 and 2.93 respectively

\section{Glass fibre}

The glass fibres used are of Cem-FIL Anti-Crack HD with modulus of elasticity $72 \mathrm{GPa}$, Filament diameter 14 microns, specific gravity 2.68 , length $12 \mathrm{~mm}$ and having the aspect ratio of 857.1. The number of fibres per $\mathrm{kg}$ is 212 millon fibres.

\section{Test specimens}

Test specimens consisting of $150 \times 150 \times 150 \mathrm{~mm}$ cubes, $150 \times 300 \mathrm{~mm}$ cylinders and $100 \times 100 \times 500$ $\mathrm{mm}$ beams were cast as shown in the Figure-1 using different grade of concrete mixers as given in Table-1 and tested as per IS: 516 and 1199.

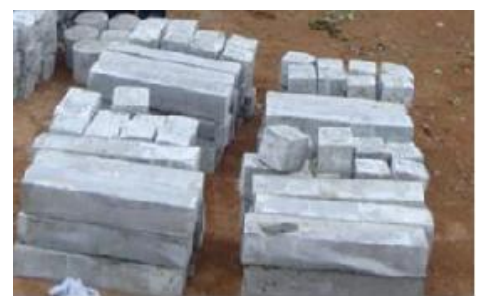

Figure-1. Specimens cast.

Table-1. Quantities of materials required per $1 \mathrm{cum}$ of ordinary concrete and glass fibre concrete mixes

\begin{tabular}{|c|c|c|c|c|c|c|}
\hline $\begin{array}{l}\text { Cinacle of } \\
\text { ennervere }\end{array}$ & $\begin{array}{c}\text { Cement } \\
(\mathrm{kg})\end{array}$ & $\begin{array}{c}\text { Fine } \\
\text { aggregate } \\
(\mathrm{kgg})\end{array}$ & $\begin{array}{c}\text { Coarse } \\
\text { aggregate } \\
(\mathrm{kg})\end{array}$ & $\begin{array}{c}\text { Water } \\
\text { (ftr) }\end{array}$ & $w / C$ ratio & Glass fibres \\
\hline M 20 & 318 & 732 & 1118 & 178 & 0.55 & \multirow{4}{*}{$\begin{array}{l}0.03 \% \text { by } \\
\text { exnostete } \\
\text { velume }\end{array}$} \\
\hline M 30 & 350 & 686 & 1137 & 178 & 0.50 & \\
\hline M 40 & 400 & 604 & 1170 & 164 & 0.40 & \\
\hline M 50 & 450 & 590 & 1142 & 163 & 0.36 & \\
\hline
\end{tabular}

\section{DISCUSSIONS OF TEST RESULTS}

Effect of glass fibre on workability of glass fibre concrete
The workability of concrete of M20, M30, M40 and M50 grades of concretes were estimated in terms of compaction factor for addition of $0.03 \%$ of glass fibre. It was observed that the addition of glass fibres, the compaction factor of 0.93 to 0.97 was maintained for almost all grades of concrete.

\section{Effect of glass fibre on bleeding of glass fibre concrete}

On the basis of the experimental study it was concluded that addition of glass fibre in concrete gives a reduction in bleeding. A reduction in bleeding improves the surface integrity of concrete, improves its homogeneity and reduces the probability of cracks occurring where there is some restraint to settlement.

Compressive strength of ordinary concrete and glass fibre concrete mixes

Table-2 gives the compressive strength values of ordinary concrete and glass fibre concrete mixes and their values are observed to be varied from 36.60 to $54.18 \mathrm{~N} / \mathrm{mm}^{2} ; 42.46$ to $62.31 \mathrm{~N} / \mathrm{mm}^{2}$ for 28 days, 39.25 to $59.96 \mathrm{~N} / \mathrm{mm}^{2 ;} 45.92$ to 69.55 $\mathrm{N} / \mathrm{mm}^{2}$ for 56 days, 43.23 to $64.37 \mathrm{~N} / \mathrm{mm}^{2} ; 51.01$ to $77.24 \mathrm{~N} / \mathrm{mm}^{2}$ for 90 days and 44.12 to 66.09 $\mathrm{N} / \mathrm{mm}^{2} ; 51.74$ to $78.61 \mathrm{~N} / \mathrm{mm}^{2}$ for 180 days.

Table-2. Compressive, flexural and split tensile strength for different grades of concrete mixes.

\begin{tabular}{|c|c|c|c|c|c|c|c|}
\hline \multirow{2}{*}{$\begin{array}{l}\text { Girade of } \\
\text { concrete }\end{array}$} & \multirow{2}{*}{$\begin{array}{l}\text { No. of } \\
\text { days }\end{array}$} & \multicolumn{2}{|c|}{$\begin{array}{l}\text { Compressive } \\
\text { Streageth } \\
\text { Nimm? }\end{array}$} & \multicolumn{2}{|c|}{ 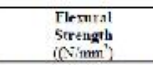 } & \multicolumn{2}{|c|}{$\begin{array}{c}\text { Split ten sile } \\
\text { Strengih } \\
\text { (Nimm) }\end{array}$} \\
\hline & & without GF & with GF & withour GF & $\begin{array}{c}\text { rith } \\
G E\end{array}$ & $\begin{array}{c}\text { nithout } \\
\text { GF }\end{array}$ & with GF \\
\hline \multirow{4}{*}{$\mathrm{M} 2 \mathrm{~N}$} & 28 & 36.60 & 42.46 & 3.52 & 4.08 & 3.52 & 4.20 \\
\hline & 56 & 39.25 & 15.92 & 3.96 & 1.59 & 4.95 & 4.21 \\
\hline & 90 & 43.23 & $5 L, 91$ & 4.18 & 4.85 & 4.33 & 5.02 \\
\hline & 180 & 44.12 & 51.74 & 4.29 & 5.02 & 4.45 & 9.25 \\
\hline \multirow{4}{*}{ M30 } & 28 & 11.50 & 18.56 & 4.12 & 4.78 & 423 & 4.91 \\
\hline & 56 & 16.6.5 & 53.42 & 157 & 5.39 & 4.68 & 5.38 \\
\hline & $x$ & 48.97 & 56.67 & 495 & 4. . $2_{2}$ & 489 & 474 \\
\hline & 180 & 49.72 & 38.17 & 498 & 5.93 & 5.12 & 0.12 \\
\hline \multirow{4}{*}{ MaO } & 28 & 47.92 & 5750 & 472 & 442 & 478 & 459 \\
\hline & 56 & 52.24 & 6n. $6 n$ & 5.28 & 6.18 & 5.35 & 0.15 \\
\hline & $\infty$ & 36.67 & 66.57 & 342 & 6.40 & 368 & 635 \\
\hline & 180 & ss.c5 & 69.66 & 591 & 6.95 & 5.94 & 699 \\
\hline \multirow{4}{*}{ MS0 } & 28 & 54.18 & 62.31 & 542 & 6.23 & 556 & 634 \\
\hline & 56 & 59.56 & 69.55 & 5.50 & 6.79 & 5.59 & 6.55 \\
\hline & $x$ & 54.37 & 37,24 & 6.43 & 7.52 & 6.39 & 7.54 \\
\hline & 180 & $\theta x . c y)$ & 78.65 & 6.57 & 7.56 & 6.65 & 7.65 \\
\hline
\end{tabular}

Split tensile strength of ordinary concrete and glass fibre concrete mixes

The split tensile strength values of ordinary concrete and glass fibre concrete mixes are observed from Table-2 varied from 3.62 to 5.56 $\mathrm{N} / \mathrm{mm}^{2} ; 4.20$ to $6.34 \mathrm{~N} / \mathrm{mm}^{2}$ for 28 days, 4.05 to $5.89 \mathrm{~N} / \mathrm{mm}^{2} ; 4.74$ to $6.66 \mathrm{~N} / \mathrm{mm}^{2}$ for 56 days, 4.33 to $6.39 \mathrm{~N} / \mathrm{mm}^{2} ; 5.02$ to $7.54 \mathrm{~N} / \mathrm{mm}^{2}$ for 90 days and 4.45 to $6.65 \mathrm{~N} / \mathrm{mm}^{2} ; 5.25$ to $7.65 \mathrm{~N} / \mathrm{mm}^{2}$ for 180 days, respectively.

Flexural strength of ordinary concrete and glass fibre concrete mixes

Table-2 gives the flexural values of ordinary concrete and glass fibre concrete mixes. The experimental setup is shown in Figure-2. These 
Galaju Sankarachari* et al. (IJITR) INTERNATI ONAL J OURNAL OF INNOVATIVE TECHNOLOGY AND RESEARCH Volume No.6, Issue No.4, June - July 2018, 8405-8408.

values are observed to be varied from 3.52 to 5.42 $\mathrm{N} / \mathrm{mm}^{2} ; 4.08$ to $6.23 \mathrm{~N} / \mathrm{mm}^{2}$ for 28 days, 3.96 to $5.80 \mathrm{~N} / \mathrm{mm}^{2} ; 4.59$ to $6.79 \mathrm{~N} / \mathrm{mm}^{2}$ for 56 days, 4.18 to $6.43 \mathrm{~N} / \mathrm{mm}^{2} ; 4.85$ to $7.52 \mathrm{~N} / \mathrm{mm}^{2}$ for 90 days and 4.29 to $6.57 \mathrm{~N} / \mathrm{mm}^{2}$; 5.02 to $7.56 \mathrm{~N} / \mathrm{mm}^{2}$ for 180 days.

Variation of compressive strength, split tensile strength and flexural strength of the ordinary concrete and glass fibre concrete mixes compared with 28 days strength

The increase in compressive strength for all the grades of concrete mixes at 56, 90, 180 days are observed to be 20 to $25 \%$ when compared with 28 days strength. The flexural and split tensile strength for all the grades of concrete mixes at 56, 90, 180 days are observed to be $20 \%$ to $25 \%$ when compared with 28 days strength. These variations can be observed in Figures 3, 4 and 5.

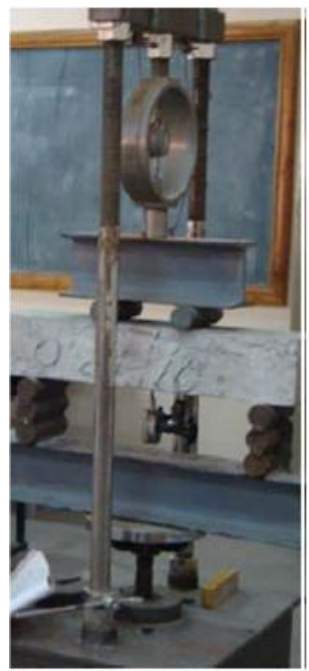

Figure 2. Experimental setup

Variation of compressive strength, split tensile strength and flexural strength of the glass fibre concrete mixes compared with ordinary concrete mixes.

Table-3 gives the increase in compressive, split tensile and flexural strength of various grades of glass fibre concrete mixes were compared with ordinary concrete mixes of M20, M30, M40 and M50. The variation in strength of glass fibre concretes is observed to be 15 to $20 \%$ when compared with ordinary concrete.

Table-3. Percentage increase of compressive, flexural and split tensile strength of glass fibre concrete in comparison with ordinary concrete mixes.
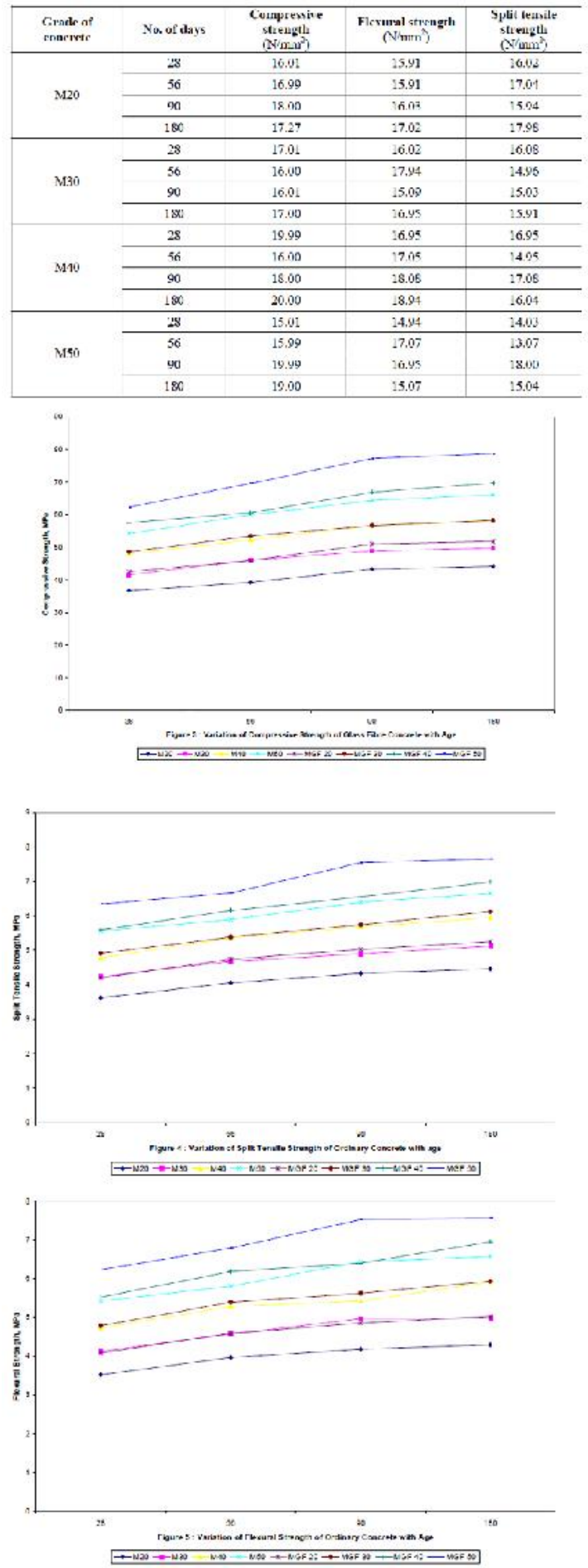

5. CONCLUSIONS

a) A reduction in bleeding is observed by addition of glass fibres in the glass fibre concrete mixes;

b) A reduction in bleeding improves the surface integrity of concrete, improves its homogeneity and reduces the probability of cracks;

c) The percentage increase of compressive strength of various grades of glass fibre 
Galaju Sankarachari* et al. (IJITR) INTERNATI ONAL J OURNAL OF INNOVATIVE TECHNOLOGY AND RESEARCH Volume No.6, Issue No.4, June - July 2018, 8405-8408.

concrete mixes compared with 28 days compressive strength is observed from 20 to $25 \%$ and

d) The percentage increase of flexural and split tensile strength of various grades of glass fibre concrete mixes compared with 28 days is observed from 15 to $20 \%$.

\section{REFERENCES}

[1]. ACI Committee 544. 1982. State-of-theReport on Fibre Reinforced Concrete, (ACI 544.1R-82),Concrete International: Design and Construction. 4(5): 9-30, American Concrete Institute, Detroit, Michigan, USA.

[2]. ACI Committee 544. 1989. Measurement of Properties of Fibre Reinforced Concrete, (ACI 544.2R-889). American Concrete Institute, Detroit, Michigan, USA.

[3]. Ganesh Babu. K and Pavan Kumar. D. 2004. Behavior of Glass Fibre Reinforced Cement Composites. ICFRC

[4]. International Conference on Fibre Composites, High Performance Concretes and Smart Materials. 8-10 Jan.,Chennai.

[5]. Griffiths R. 2000. An assessment of the properties and degradation behaviour of glass-fibre-reinforced polyesterpolymer concrete. Composites Science and Technology.pp. 2747-2753.

[6]. Naaman A.E. 1985. Fibre Reinforcement for Concretes, Concrete International: Design and Construction. 7(3): 21-25.

[7]. Parviz Soroushian. 1991. Fiber - Type Effects on thePerformance of Steel Fiber Reinforced Concrete. ACI Materials Journal. March-April 1991. pp. 129-134.

[8]. Srinivasa Rao and Seshadri Sekhar T. 2005. Strength and Durability Properties of Glass Fibre Reinforced Concrete.

[9]. Proceedings of the International Conference on Recent Advances in Concrete and Construction Technology.December 7-9, SRMIST, Chennai, India. pp. 43-50.

[10]. Singh S.P, Mohammadi Y and Kaushik S.K. 2005.Flexural Fatigue Analysis of Steel Fibrous ConcreteContaining Mixed Fibres. ACI Mater. J. 102(6): 438-444.

\section{AUTHOR's PROFILE}

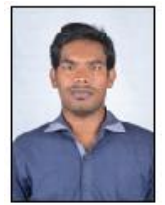

Galaju Sankarachari, Pursuing M.Tech (STRUCTURAL) from SKR College of Engineering \& Technology, Manubolu, SPSR Nellore.

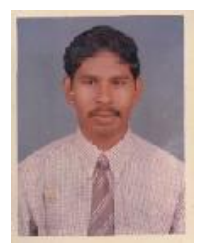

R. Balamurugan, Ph.D, Associate Professor in Deportment of Civil, SKR College of Engineering \& Technology, Manubolu, SPSR Nellore 